\title{
Utility of pearl millet landraces in breeding dual-purpose hybrids for arid zone environments of India
}

\author{
Om Parkash Yadav $\cdot$ Francis R. Bidinger • \\ Dharam V. Singh
}

Received: 2 April 2008 / Accepted: 16 October 2008 / Published online: 7 November 2008

(C) Springer Science+Business Media B.V. 2008

\begin{abstract}
In pearl millet (Pennisetum glaucum (L.) $\mathrm{R}$. Br.), single cross hybrids based largely on exotic germplasm, have found very limited adoption in drought-prone arid regions mainly due to their inadequate adaptation to prevalent extremely harsh agroclimatic conditions. This study tested the hypothesis that the use of restorer parents derived from adapted landrace germplasm could be an alternative strategy in developing suitable hybrids for arid regions. Forty inbred restorer lines developed from two phenotypically diverse landraces were used to develop hybrids evaluated in this study for their performance in five typical arid zone environments between 2003 and 2007. Inbred lines from both landrace populations differed significantly in their combining ability for biomass, harvest index and grain and stover yields. A larger proportion of experimental hybrids, based on selected inbred lines, significantly outperformed the commercial checks for grain and stover yields. Increase in grain and stover yields was achieved primarily due to their higher biomass productivity, with no decline in harvest index. Choice of landrace determined the relative grain and stover productivity of
\end{abstract}

O. P. Yadav $(\bowtie) \cdot$ D. V. Singh

Central Arid Zone Research Institute, Jodhpur

342003 , India

e-mail: opyadav@cazri.res.in; opyadav21@yahoo.com

F. R. Bidinger

International Crops Research Institute for the Semi-Arid

Tropics, Patancheru 502 324, India their hybrids. Phenotypic differences observed in parental landraces in tillering and panicle length were also visible in their respective hybrids, indicating that characteristics of landrace parental populations were transmitted in their hybrids.

Keywords Drought $\cdot$ Arid zone $\cdot$ Breeding . Hybrids · Pearl millet $\cdot$ Pennisetum glaucum

\section{Introduction}

The arid region of north-western India is marginal and climatically variable compared to other arable zones in the country rendering arable cropping a risky preposition. Drought resilient pearl millet [Pennisetum glaucum (L.) R. Br.] is the major cereal crop in the arid regions and its grain is the major source of dietary carbohydrates. In addition, millet stover is main ration during long dry season for livestock. During the last four decades, average pearl millet grain yields have more than doubled, largely due to the increasing cultivation of single cross hybrids (Khairwal and Yadav 2005). The extent of adoption of hybrid cultivars, however, has not been uniform. There has been much adoption in areas with relatively more favourable climate and soil conditions. In contrast, hybrid adoption has been very limited in the arid zone of the North West India which represents about $25 \%$ of the pearl millet acreage in the country (Khairwal and Yadav 2005). Arid zone farmers still cultivate stress-adapted 
traditional landraces on a large scale, principally as a strategy to minimize the risk of crop failure as farmers perceive that hybrids with proven high yield potential in favourable environments have a greater risk of crop failure, compared to landraces, if grown under severe drought stress conditions (Kelley et al. 1996; Christinck 2002) due to lack of adaptation to arid conditions (Yadav and Weltzien 2000; vom Brocke et al. 2003; Bidinger et al. 2006; Yadav and Bidinger 2007).

The major emphasis in Indian hybrid breeding has been on high productivity, with selection and evaluation conducted in favourable environments. Moreover, the germplasm base used in most breeding programs does not include arid zone materials and hence lacks specific adaptation to the physical environments of the arid zone (Presterl and Weltzien 2003; Bidinger et al. 2006). With selection emphasis based on high grain yield, and ultimately high harvest index, most conventional hybrids do not provide adequate stover quantity or quality (Kelley et al. 1996; Christinck 2002) to be a viable alternative to farmers' landraces.

In order to simultaneously improve yield and adaptation to the stress environments of the arid zone, breeding programs need to use genetic materials which possess both traits. One approach could be through the use of adapted arid zone landrace germplasm to breed restorer parents for conventional single cross hybrids. This approach combines an increased productivity through heterosis, with the necessary adaptation via the restorer line which has been demonstrated in the breeding of topcross (inbred $\times$ population) hybrids (Bidinger et al. 1994; Yadav et al. 2000a, b). Because of a strong market preference for single cross hybrids, a collaborative program between the Central Arid Zone Research Institute (CAZRI) and the International Crops Research Institute for the Semi-Arid Tropics (ICRISAT) has developed a set of restorer populations based on arid zone germplasm, as sources of inbred restorers for hybrids breeding programs targeting arid zone (Bidinger and Yadav 2008). The research reported here provides an initial test of the hypothesis that inbred lines derived from such populations can produce hybrids that are superior to conventionally bred hybrids in the arid zone. Specifically, this paper describes the breeding and evaluation of experimental inbred restorer lines from progenies selected to form the basis of two landrace-based restorer populations; assesses the differences, if any, in their ability to pro- duce better yielding, arid zone adapted hybrids and finally evaluates performance of experimental hybrids based on restorer lines.

\section{Materials and methods}

\section{Genetic materials}

Two pearl millet landrace populations (Barmer and Jakharana) used in this study as a source of inbred restorers originated in Rajasthan. However, these populations represent two different origins and have very distinct plant types. The Barmer population (BR) is based on landraces from Barmer district of the arid zone of western Rajasthan and is characterized by high tillering, thin stems, and thin, medium long and loose panicles (Yadav and Weltzien 1998). In contrast, the Jakharana (JK) population is a landrace from central Rajasthan with moderate tillering ability, tall and has long and compact panicles (Khairwal et al. 2004). Restorer versions of both populations were initiated in 1998 dry season with the production of approximately 500 self-pollinated progenies from each population (Table 1). These were grown in the arid zone in the rainy season of 1999 in an unreplicated observation nursery; progenies were scored for flowering, uniformity, trueness to the original landrace type and agronomic value. Sixty-four progenies were selected from each population on the basis of these data, reserve seed planted in the dry season at ICRISAT and progenies testcrossed on male-sterile (A-line) tester 841A (JK) or 94444A (BR) in the dry season of 1999/2000 (Table 1). Testcrossed progenies were evaluated in the arid zone in the rainy season of 2000, and data recorded on flowering time, grain and stover yields, downy mildew incidence and agronomic score. Based on the data of this trial the 25 best progenies in each population were selected and recombined by hand pollination, using reserve S1 seed in the dry season of 2000/2001 at ICRISAT (Table 1), to make the $\mathrm{C} 1$ (first cycle bulk) of the restorer population. The bulk was random-mated again in 2001/2002 dry season to form the C2 bulk and at the same time testcrossed to 12 different A-lines. The resulting topcross hybrids of both populations were yield tested in the 2003 rainy season; the results of these tests have been reported by Bidinger and Yadav (2008). 
Table 1 Chronology of the development and evaluation of (1) the Barmer and Jakharana restorer populations of pearl millet and (2) inbred restorer lines from each population

\begin{tabular}{|c|c|c|c|}
\hline \multirow[t]{2}{*}{ Year } & \multirow[t]{2}{*}{ Season } & \multicolumn{2}{|l|}{ Breeding operation } \\
\hline & & Restorer population & Experimental restorer lines/hybrids \\
\hline 1998/1999 & Dry & $\begin{array}{l}\text { Production of }>500 \mathrm{~S} 1 \text { progenies } \\
\text { from each population }\end{array}$ & \\
\hline 1999 & Rainy & $\begin{array}{l}\text { Selection of } 64 \text { superior S1's from } \\
\text { each population for making } \\
\text { restorer populations }\end{array}$ & \\
\hline $1999 / 2000$ & Dry & $\begin{array}{l}\text { Testcrossing selected S1's to } \\
\text { selected seed parents }\end{array}$ & $\begin{array}{l}\text { Advance selected } \mathrm{S} 1 \text { to } \mathrm{S} 2 \\
\text { without selection }\end{array}$ \\
\hline 2000 & Rainy & $\begin{array}{l}\text { Evaluation of } \mathrm{S} 1 \text { testcrosses for } \\
\text { restoration and productivity }\end{array}$ & $\begin{array}{l}\text { Advance } \mathrm{S} 2 \text { to } \mathrm{S} 3 \text { with selection } \\
\text { for type/productivity/resistance }\end{array}$ \\
\hline $2000 / 2001$ & Dry & $\begin{array}{l}\text { Random-mating of selected } \mathrm{S} 1 \text { to make } \\
\mathrm{C} 1 \text { generation of restorer composite }\end{array}$ & Advance $\mathrm{S} 3$ to $\mathrm{S} 4$ without selection \\
\hline 2001 & Rainy & - & $\begin{array}{l}\text { Advance S4 to S5 with selection } \\
\text { for type/productivity/resistance }\end{array}$ \\
\hline $2001 / 2002$ & Dry & $\begin{array}{l}\text { Random mating of restorer composite } \\
\mathrm{C} 1 \text { generation to make } \mathrm{C} 2 \text { generation }\end{array}$ & Advance S5 to S6 without selection \\
\hline 2002 & Rainy & Season lost due to lack of rainfall & Season lost due to lack of rainfall \\
\hline $2002 / 2003$ & Dry & $\begin{array}{l}\text { Testcrossing of } \mathrm{C} 2 \text { generation } \\
\text { bulks to A-lines }\end{array}$ & $\begin{array}{l}\text { Testcrossing of } 20-23 \text { S6 lines } \\
\text { per population to } 3 \text { A-lines }\end{array}$ \\
\hline 2003 & Rainy & $\begin{array}{l}\text { Evaluation of testcross performance } \\
\text { of C } 2 \text { bulks (Bidinger and Yadav 2008) }\end{array}$ & $\begin{array}{l}\text { Evaluation of testcross performance } \\
\text { of S6 lines }\end{array}$ \\
\hline $2004 / 2005$ & Dry & & $\begin{array}{l}\text { Seed production of experimental } \\
\text { hybrids with selected S6 lines }\end{array}$ \\
\hline 2005 & Rainy & & Evaluation of full set of experimental hybrids \\
\hline 2006 & Rainy & & Evaluation of full set of experimental hybrids \\
\hline 2007 & Rainy & & Evaluation of selected experimental hybrids \\
\hline
\end{tabular}

Between 1999 and 2002 the same 64 S1 progenies were inbred by selfing for two generations per year (Table 1). During the dry season, progenies were selfed and advanced without selection at ICRISAT; while plants were selfed and selected at harvest for plant type and productivity during the rainy season at CAZRI (Table 1). A total of 20 S6 lines from JK and 23 from BR were selected and testcrossed in dry season of 2002/ 2003. Three selected A-lines, ICMA 88004, ICMA 91444 and ICMA 00222 were used for testcrossing with BR inbreds and ICMA 97111, ICMA 97333 and ICMA 98222 with JK inbreds. Inbreds were evaluated for their combining ability for grain and stover yields in replicated trials at two arid zone locations in the rainy season of 2003 (Table 1). Eight BR S6 lines and 12 JK S6 lines were finally selected on the basis of their general combining ability (GCA) to develop single cross experimental hybrids on a range of male sterile lines.
Field evaluations and data recording

All the evaluations were carried out in arid zone in the rainy (July to September) seasons of 2003 for S6 combining ability trials and 2005-2007 for experimental hybrid trials. The 2003 trials were conducted at CAZRI, Jodhpur and the Research Substation of the Rajasthan Agricultural University at Nagaur. In 2005-2006 the 63 experimental hybrids on JK inbred lines and the 37 hybrids on the BR inbreds were evaluated at CAZRI in separate replicated trials. Three checks, consisting of extra early maturing hybrid HHB 67 and medium maturing hybrids ICMH 356 and RHB 121 were also included in each trial. During 2007, 13 hybrids selected from these two trials were evaluated in one combined trial, along with two checks, HHB 67 and ICMH 356. 
The S6 progeny testcross trials were conducted in $5 \times 12$ for JK progenies and $5 \times 15$ alpha design for BR progenies with four replications. The experimental hybrid trials were conducted in randomized complete block trials with three replications. For the combining ability trials and S6 progeny experimental hybrid trials, single rows of $4 \mathrm{~m}$ length spaced at $0.6 \mathrm{~m}$ with an approx plant-to-plant spacing of $15 \mathrm{~cm}$ within rows were used.

Flowering time was recorded as number of days from sowing to emergence of stigma in the main panicles of $50 \%$ plants in a plot. At maturity, plants per plot were counted and the panicle length was recorded on five randomly taken plants and mean panicle length recorded. At harvest, all the panicles were cut, counted and sundried in bags; they were weighed, threshed and grain weight recorded. Stover was cut at ground level, bundled, sun-dried in the field for 2-3 weeks and weighed. Panicle weight and stover weight were added to obtain biomass. The harvest index was calculated as ratio of grain to total biomass expressed in percentage. Market value of hybrids and checks was quantified by overall crop value, based on a weighted (3:1) average of the relative value of pearl millet grain (Rs. 6,000 $\mathrm{t}^{-1}$ ) and stover (Rs. 2,000 $\mathrm{t}^{-1}$ ) in western Rajasthan market.

Data analysis

Data from all trials were analyzed according to the experimental design for both individual environments as well as across environments. GCA for each restorer inbred line was estimated as the mean of all crosses involving that line minus the overall mean. Significance of the line GCA was determined by $t$-test. The mean performance of checks and experimental hybrids was tested following between-group comparisons through contrast analysis (Gomez and Gomez 1984).

\section{Results and discussion}

Evaluation environments

The years varied considerably in the amount and distribution of rainfall, which primarily determined the trial productivity (Table 2). The total rainfall in 2003 was $519 \mathrm{~mm}$ at Nagaur of which $80 \%$ fell in July, and $328 \mathrm{~mm}$ at Jodhpur. Crop growth was good despite the skewed rainfall distribution, with average biomass yields of greater than $650 \mathrm{~g} \mathrm{~m}^{-2}$ and an average grain yield of $167 \mathrm{~g} \mathrm{~m}^{-2}$. The years 2005, 2006 and 2007 at CAZRI were characteristically drought affected. The amount of rainfall during these seasons varied from $188 \mathrm{~mm}$ in 2005 to $229 \mathrm{~mm}$ in 2007 . The trials faced drought spells of 2-3 weeks immediately after sowing in 2005 and 2007, which resulted in delayed flowering (Table 2). In 2006 growing conditions were relative better during early vegetative stages. In 3 years, most of the rain occurred during pre-flowering period. The post-flowering stage was characterized by severe moisture stress resulting in mean grain yields ranging from 69.3 to $88.4 \mathrm{~g} \mathrm{~m}^{-2}$ and mean biomass yield ranging from 369.0 to $518.1 \mathrm{~g} \mathrm{~m}^{-2}$ (Table 2). In 2005 and 2007, moisture stress after flowering severely affected grain filling and reduced harvest index (Table 2). The experiments also encountered moisture stress in post-flowering period in 2006 but it was not as severe as in 2005 and 2007 seasons. As a result harvest index was 5-11\% higher in the 2006 season. The environmental conditions encountered during evaluations provided excellent opportunities to assess the performance of landrace-based hybrids under average to below average arid zone rainfall patterns, indicating that results are clearly depictive of drier environments of arid zone.

\section{Performance of testcrosses}

There were significant differences among testcrosses for biomass, grain and stover yields and harvest index in JK and BR line trials in both stages of testing (data not presented). In the initial stage, the mean biomass of the JK and BR line testcrosses was similar, but the mean harvest index of JK line testcrosses was $8 \%$ higher than those of BR (Table 3). As a result, grain yield of JK testcrosses was $47 \mathrm{~g} \mathrm{~m}^{-2}$ higher than BR testcrosses. The differences between the JK and BR S6 test testcrosses was similar to the differences between testcrosses of their parental restorer populations (Bidinger and Yadav 2008) which suggests that characteristics of landrace parental populations are retained in inbreds derived from them.

There were significant differences in combining ability among the S6 lines from both populations for all productivity traits (Table 4). About $50 \%$ of the lines in each population had significant positive or negative GCA estimates across traits, with the remaining lines having a non-significant GCA. GCA 
Table 2 Mean flowering time, biomass, harvest index and mean grain and stover yields of pearl millet at Jodhpur and Nagaur during 4 years of evaluations

The sowing dates and rainfall amount is also given

Table 3 Summary of the testcross performance of 20-23 S6 lines bred from Barmer and Jakharana S1 progenies used in the making of the restorer versions of the two pearl millet populations

Data are S6 line means of replicated trials at CAZRI, Jodhpur and RAU, Nagaur in 2003

Table 4 Summary of general combining ability (GCA) estimates of 20-23 S6 lines of Barmer and Jakharana populations of pearl millet

\begin{tabular}{|c|c|c|c|c|c|}
\hline \multirow[t]{2}{*}{ Trait } & \multicolumn{2}{|l|}{2003} & \multirow{2}{*}{$\begin{array}{l}2005 \\
\text { Jodhpur }\end{array}$} & \multirow{2}{*}{$\begin{array}{l}2006 \\
\text { Jodhpur }\end{array}$} & \multirow{2}{*}{$\begin{array}{l}2007 \\
\text { Jodhpur }\end{array}$} \\
\hline & Nagaur & Jodhpur & & & \\
\hline Days to flower (no.) & 54 & 42 & 51 & 42 & 56 \\
\hline Grain yield $\left(\mathrm{g} \mathrm{m}^{-2}\right)$ & 115 & 220 & 69 & 88 & 69 \\
\hline Stover yield $\left(\mathrm{g} \mathrm{m}^{-2}\right)$ & 257 & 553 & 368 & 218 & 219 \\
\hline Biomass $\left(\mathrm{g} \mathrm{m}^{-2}\right)$ & 420 & 885 & 518 & 369 & 369 \\
\hline Harvest index (\%) & 27.2 & 24.9 & 13 & 24 & 19 \\
\hline Sowing date & 9 July & 12 July & $4 \mathrm{Jul}$ & 11 Aug & $9 \mathrm{Jul}$ \\
\hline Total rainfall & 519 & 328 & 188 & 208 & 229 \\
\hline Pre-flowering rains & 437 & 273 & 167 & 189 & 166 \\
\hline Post-flowering rains & 82 & 55 & 21 & 18 & 62 \\
\hline
\end{tabular}

\begin{tabular}{lllll}
\hline & $\begin{array}{l}\text { Total biomass } \\
\left(\mathrm{g} \mathrm{m}^{-2}\right)\end{array}$ & $\begin{array}{l}\text { Harvest } \\
\text { index }(\%)\end{array}$ & $\begin{array}{l}\text { Grain yield } \\
\left(\mathrm{g} \mathrm{m}^{-2}\right)\end{array}$ & $\begin{array}{l}\text { Stover yield } \\
\left(\mathrm{g} \mathrm{m}^{-2}\right)\end{array}$ \\
\hline $\begin{array}{l}\text { Jakharana S6 lines } \\
\text { Average }\end{array}$ & 646 & 29.7 & 187 & 385 \\
SE & 28.9 & 1.05 & 10.7 & 18.4 \\
$P<$ entry differences & 0.001 & 0.001 & 0.001 & 0.001 \\
Barmer S6 lines & & & & \\
Average & 639 & 21.8 & 140 & 418 \\
SE & 24.0 & 0.99 & 10.3 & 24.0 \\
$P<$ entry differences & 0.001 & 0.001 & 0.001 & 0.001 \\
\hline
\end{tabular}

\begin{tabular}{|c|c|c|c|c|}
\hline & $\begin{array}{l}\text { Total biomass } \\
\left(\mathrm{g} \mathrm{m}^{-2}\right)\end{array}$ & $\begin{array}{l}\text { Harvest } \\
\text { index }(\%)\end{array}$ & $\begin{array}{l}\text { Grain yield } \\
\left(\mathrm{g} \mathrm{m}^{-2}\right)\end{array}$ & $\begin{array}{l}\text { Stover yield } \\
\left(\mathrm{g} \mathrm{m}^{-2}\right)\end{array}$ \\
\hline \multicolumn{5}{|l|}{ Jakharana S6 lines } \\
\hline Range in GCA estimates & -35 to +65 & -1.8 to +1.4 & -13 to +22 & -21 to +36 \\
\hline Lines with +significant GCA & 4 & 6 & 2 & 5 \\
\hline Lines with - significant GCA & 5 & 5 & 3 & 6 \\
\hline \multicolumn{5}{|l|}{ Barmer S6 lines } \\
\hline Range in GCA estimates & -47 to +37 & -1.9 to +1.6 & -12 to +20 & -36 to +39 \\
\hline Lines with +significant GCA & 6 & 7 & 3 & 6 \\
\hline Lines with - significant GCA & 3 & 7 & 4 & 6 \\
\hline
\end{tabular}

estimates for biomass productivity among individual lines ranged from -47 to $+37 \mathrm{~g} \mathrm{~m}^{-2}$ in the BR population and -35.0 to $+64.6 \mathrm{~g} \mathrm{~m}^{-2}$ in $\mathrm{JK}$ testcrosses. Similarly, there was a wide range in the GCA estimates for harvest index and grain and stover yields (Table 4) which should provide ample opportunity to select good combining lines that may be used to produce hybrids on pre-selected A-lines with different combinations of grain and stover yields.
The second stage of testing, which included appropriate checks, permitted a comparative assessment of landrace pollinator-based single cross hybrids and commercial checks. The hybrids based on inbreds derived from the two landrace sources were significantly different for biomass, grain and stover yields, harvest index and flowering time (Table 5), and more importantly, as a group had a highly significant greater grain and stover productivity compared to the established checks. The 
Table 5 Summary of the evaluation of the hybrids performance based on the inbred pollinators derived from the Barmer and Jakharana restorer populations

\begin{tabular}{|c|c|c|c|c|c|}
\hline & $\begin{array}{l}\text { Biomass } \\
\left(\mathrm{g} \mathrm{m}^{-2}\right)\end{array}$ & $\begin{array}{l}\text { Harvest } \\
\text { index }(\%)\end{array}$ & $\begin{array}{l}\text { Grain yield } \\
\left(\mathrm{g} \mathrm{m}^{-2}\right)\end{array}$ & $\begin{array}{l}\text { Stover yield } \\
\left(\mathrm{g} \mathrm{m}^{-2}\right)\end{array}$ & $\begin{array}{l}\text { Days to } \\
\text { flower }\end{array}$ \\
\hline \multicolumn{6}{|l|}{ JK-based hybrids } \\
\hline Trial mean & 423.8 & 17.0 & 70.7 & 283.4 & 46.0 \\
\hline$P<$ entry differences & $<0.001$ & $<0.001$ & $<0.001$ & $<0.001$ & $<0.001$ \\
\hline SE & 21.1 & 1.15 & 5.3 & 16.9 & 0.50 \\
\hline Checks average* & $375.4 \mathrm{a}$ & $16.1 \mathrm{a}$ & $54.0 \mathrm{a}$ & $244.7 \mathrm{a}$ & $45.1 \mathrm{a}$ \\
\hline Hybrid average & $426.1 \mathrm{~b}$ & $17.1 \mathrm{a}$ & $71.5 b$ & $285.3 b$ & $46.0 \mathrm{a}$ \\
\hline Hybrid range & $228.0-683.9$ & $5.3-27.2$ & $16.9-129.6$ & $142.6-503.4$ & $41.8-51.5$ \\
\hline Number of hybrids $>$ best check $(P<0.05)$ & 10 & 1 & 23 & 6 & 0 \\
\hline \multicolumn{6}{|l|}{ BR-based hybrids } \\
\hline Trial mean & 463.3 & 19.9 & 87.0 & 302.6 & 46.7 \\
\hline$P<$ entry differences & $<0.001$ & $<0.001$ & $<0.001$ & $<0.001$ & $<0.001$ \\
\hline SE & 17.8 & 0.95 & 4.89 & 15.0 & 0.56 \\
\hline Checks average & $369.8 \mathrm{a}$ & $19.9 \mathrm{a}$ & $71.7 \mathrm{a}$ & $215.9 \mathrm{a}$ & $44.9 \mathrm{a}$ \\
\hline Hybrid average & $470.9 b$ & $19.9 \mathrm{a}$ & $88.2 \mathrm{~b}$ & $309.6 b$ & $46.8 \mathrm{a}$ \\
\hline Hybrid range & $308.6-685.9$ & $14.7-26.5$ & $41.0-123.5$ & $191.0-503.4$ & $44.2-50.9$ \\
\hline Number of hybrids $>$ best check $(P<0.05)$ & 26 & 0 & 2 & 31 & 0 \\
\hline
\end{tabular}

Data are means of 63 crosses in JK population and 37 crosses in BR on 6-7 A lines evaluated in replicated trials at Jodhpur in 2005 and 2006

* Mean performance of checks and experimental hybrids suffixed by different letter within a column is statistically different at $P<0.05$

average biomass and grain yield of JK and BR hybrids was $14-28 \%$ and $23-32 \%$ higher than the checks, respectively. The similarity in harvest index between hybrids and checks suggested that the primary difference obtained in grain yield was due to their differential ability to produce biomass. The significantly higher levels of biomass in landrace-based hybrids, with a similar harvest index as of commercial checks, resulted in a significantly higher stover yield than checks (Table 5). Thus both greater biomass production and its partitioning to grain yield are critical factors in simultaneously improving grain and stover yields.

For areas such as the arid zone often characterized by drought years, pearl millet stover is as important as grain (Kelley et al. 1996). The ability of the landracebased hybrids to increase biomass without a reduction in harvest index, compared to the commercial checks, is of particular value. In contrast, the major gains in grain yield in cereal in favourable areas have historically been achieved through greater partitioning of biomass to grain, rather than increasing the overall biomass (Austin et al. 1993). The strategy of increasing grain yield is less applicable in marginal environments of arid regions than it is for favorable regions, for several reasons: (1) Traditional adaptive mechanisms in marginal environments, such as deep rooting, asynchronous tiller development, maintenance of stem carbohydrate reserves, etc., are likely to involve the partitioning of significant amounts of biomass to vegetative tissues (Bidinger and Hash 2004). (2) The addition of even very modest amounts of organic matter to the soil, by direct or indirect (via animal manure) return of crop residues, is essential to the maintenance of soil fertility in many arid zone soils (Agarwal et al. 1997). (3) There is greater importance of pearl millet stover as feed for ruminants in arid regions, as the sale of animals and animal products is often the major source of household cash income (Hall et al. 2004). Thus a far more realistic model for the genetic improvement of staple crops for the marginal environments of arid regions is to improve biomass productivity while maintaining existing levels of harvest index. The approach of landrace-based hybrids is effective in amalgamating the higher biomass heterosis with adapted landrace pollinators (Bidinger et al. 2003; Bidinger and Yadav 
2008), and improved partitioning to grain achievable in hybrids resulting in the improvement of grain yield without any adverse effect on stover yield.

While landrace-based hybrids in general had significantly greater grain and stover productivity compared to the checks, the choice of landrace as base population appeared to determine the relative grain and stover productivity of its hybrids (Table 5). The BR inbreds produced hybrids with $44 \%$ higher stover yield than checks. Of the 37 hybrids, 31 produced significantly more stover than the top yielding check, and two of these produced a significantly higher grain yield than the best check. On the other hand, the JK inbreds produced hybrids with a $32 \%$ higher mean grain yield with a $17 \%$ higher stover yield than the checks. While 23 of $67 \mathrm{JK}$ hybrids produced a significantly higher grain yield than top yielding check, only six hybrids had significantly higher stover yield (Table 5).

The average flowering time of landrace-based hybrids and checks was comparable under the trial conditions (Table 3) which ensured that neither group had an advantage or disadvantage due to its phenology, as earliness in pearl millet results in escaping the terminal moisture stress (Bidinger and Witcombe 1989; Mahalakshmi et al. 1988; van Oosterom et al. 1995, 1996).
However, actual flowering date under the stress conditions of the arid zone is often associated with genetic and environmental effects often associated with preflowering drought stress. Therefore, any expected earlier flowering of check variety especially HHB 67, which flowers in 45 days under non-stress conditions (Khairwal et al. 2004) was not realized under the trial conditions. Thus the differences in the performance of landrace-based hybrids was most likely due to their better adaptation to drought stress, gained from their landrace pollinators, rather than to their drought escape. These are very significant findings as this magnitude of superiority was across a good number of conventional A-lines available for hybrid breeding.

\section{Performance of selected hybrids}

The potential benefit from growing landrace-based hybrids in drought prone arid zone environments was confirmed with testing of selected hybrids from 2005 to 2006 evaluations for one additional season in 2007 . All of the selected hybrids based on the JK and BR inbreds produced a higher grain yield with $50 \%$ of them being significantly better than top yielding check ICMH 356 (Table 6). Plus the stover yield of

Table 6 Flowering time, biomass, harvest index, grain and stover yields and other phenotypic traits in selected hybrids based on inbreds derived from Jakhanrana and Barmer populations

\begin{tabular}{|c|c|c|c|c|c|c|c|c|}
\hline Hybrid & $\begin{array}{l}\text { Days to } \\
\text { flower }\end{array}$ & $\begin{array}{l}\text { Panicle } \\
\text { length } \\
(\mathrm{cm})\end{array}$ & $\begin{array}{l}\text { No. of } \\
\text { panicles } / \mathrm{m}^{2}\end{array}$ & $\begin{array}{l}\text { Grain } \\
\text { yield } \\
\left(\mathrm{g} \mathrm{m}^{-2}\right)\end{array}$ & $\begin{array}{l}\text { Stover } \\
\text { yield } \\
\left(\mathrm{g} \mathrm{m}^{-2}\right)\end{array}$ & $\begin{array}{l}\text { Biomass } \\
\left(\mathrm{g} \mathrm{m}^{-2}\right)\end{array}$ & $\begin{array}{l}\text { Harvest } \\
\text { index } \\
(\%)\end{array}$ & $\begin{array}{l}\text { Market } \\
\text { value } \\
\text { (Rs./ha) }\end{array}$ \\
\hline 00222A x J1 & 51.6 & 25.2 & 11.3 & 98.8 & 324.0 & 521.1 & 19.5 & 12,408 \\
\hline $00222 \mathrm{~A} \times \mathrm{J} 3$ & 51.1 & 23.0 & 11.5 & 74.6 & 251.1 & 396.9 & 19.2 & 9,498 \\
\hline $91444 \mathrm{~A} \times \mathrm{J} 3$ & 49.9 & 27.1 & 10.7 & 64.2 & 215.3 & 345.1 & 16.3 & 8,158 \\
\hline $97111 \mathrm{~A} \times \mathrm{J} 3$ & 48.8 & 24.7 & 10.8 & 69.2 & 218.7 & 372.4 & 18.1 & 8,526 \\
\hline $97333 \mathrm{~A} \times \mathrm{J} 2$ & 49.1 & 26.8 & 14.3 & 97.0 & 422.4 & 601.5 & 16.7 & 14,268 \\
\hline $97444 \mathrm{~A} \times \mathrm{J} 1$ & 47.4 & 27.2 & 10.6 & 97.8 & 246.5 & 409.7 & 24.3 & 10,798 \\
\hline $97444 \mathrm{~A} \times \mathrm{J} 2$ & 45.6 & 27.8 & 13.4 & 77.8 & 303.2 & 466.8 & 17.1 & 10,732 \\
\hline $97444 \mathrm{~A} \times \mathrm{J} 4$ & 46.6 & 23.0 & 14.5 & 75.8 & 224.5 & 378.8 & 19.7 & 9,038 \\
\hline $98222 \mathrm{~A} \times \mathrm{J} 12$ & 52.7 & 25.5 & 7.7 & 74.8 & 268.5 & 411.9 & 17.7 & 9,858 \\
\hline $00222 \mathrm{~A} \times \mathrm{B} 1$ & 50.2 & 21.0 & 13.5 & 92.7 & 280.1 & 454.2 & 20.7 & 11,164 \\
\hline $97333 \mathrm{~A} \times \mathrm{B} 2$ & 52.0 & 21.7 & 16.8 & 94.9 & 371.5 & 562.4 & 17.7 & 13,124 \\
\hline $97333 \mathrm{~A} \times \mathrm{B} 3$ & 50.7 & 22.7 & 16.2 & 100.3 & 416.6 & 596.7 & 18.1 & 14,350 \\
\hline $98222 \mathrm{~A} \times \mathrm{B} 4$ & 50.0 & 21.4 & 10.9 & 106.2 & 276.6 & 466.8 & 23.4 & 11,904 \\
\hline ICMH 356 & 49.2 & 20.5 & 11.1 & 64.0 & 263.9 & 395.9 & 17.8 & 9,118 \\
\hline ННВ 67 & 43.6 & 19.8 & 12.0 & 59.0 & 151.4 & 270.9 & 22.1 & 6,568 \\
\hline LSD & 1.3 & 1.3 & 1.7 & 14.3 & 35.3 & 47.5 & 3.6 & - \\
\hline
\end{tabular}

Data are means of replicated trials in 2005-2007 at Jodhpur 
all of the JK and BR hybrids was significantly higher than that of HHB 67 and more than one-third of the JK and BR hybrids also produced significantly higher stover yield than ICMH 356.

The differences in the parental landrace phenotypes were also visible in their hybrids. Hybrids based on pollinators derived from the high tillering BR population had a higher number of panicles (14.4) than those based on pollinators derived from the low tillering JK population (11.6). The longer panicles characteristic of the JK population was also evident in its hybrids, confirming earlier observation that phenotypic traits in landraces were transmitted to their hybrids across a wide range of A-lines. Landrace-based hybrids offered a mean crop value advantage of $30 \%$ over better check, with the best hybrids providing more than $50 \%$ advantage in total crop value (Table 6). The data clearly demonstrated that landrace-based populations are a viable and potential source to derive inbred restorer lines needed for developing dual-purpose adapted hybrids for arid zone environments. The importance of landraces in breeding for drought conditions has been very well documented (Weltzien and Fischbeck 1990; Ceccarelli et al. 1991; Yadav and Weltzien 2000; vom Brocke et al. 2002; Yadav and Bidinger 2007) but unfortunately the green revolution model, based on exotic germplasm, which has been highly successful for favourable environments supporting potential yield has also been extended to marginal and arid areas. This approach ignored the fact that the major determinant of crop performance under drought prone environments is stress adaptation (Bidinger et al. 1987; Ceccarelli and Grando 1991; Simmonds 1991; Ceccarelli 1994; Ceccarelli et al. 1998) with potential yield playing only a secondary role (Bidinger et al. 1987). The utilization of traditional drought-adapted landraces as sources of pollinators offers a great promise to extend the benefit of pearl millet hybrid technology to more marginal environments, as clearly demonstrated in this study.

The use of landrace-based hybrids will be a modern form of conservation of the valuable traits to be found in fast-eroding traditional genetic resources. The retention of such traits in a modern and more productive cultivar form will assure that the benefits of centuries of human and natural selection for adaptation to the stresses of arid zone environments will remain available for future generations.

\section{Conclusions}

The very high proportion of landrace-based hybrids which out yielded the best available checks for the arid zone underscores several points. Firstly, the chances of identifying adapted productive hybrids based on landrace-derived pollinators are very high, considering that only 100 hybrids were evaluated in the initial yield trials (2005 and 2006), and yet a relatively high number of them significantly outperformed the commercial checks. Secondly, the enormous advantage in grain and stover yields of landrace-based hybrids over the established checks highlights the value of landraces in developing welladapted hybrids for drought-prone areas.

\section{References}

Agarwal RK, Kumar P, Power JF (1997) Use of crop residue and manure to conserve water and enhance nutrient availability and pearl millet yield in an arid tropical region. Soil Tillage Res 41:43-51. doi:10.1016/S0167-1987(96)01082-3

Austin RB, Ford MA, Morgan CL, Yeoman D (1993) Old and modern wheat cultivars compared on the Broadbalk wheat experiment. Eur J Agron 2:141-147

Bidinger FR, Hash CT (2004) Pearl millet. In: Nguyen HT, Blum A (eds) Physiology and biotechnology integration for plant breeding. Marcel Dekker, New York, pp 225-270

Bidinger FR, Witcombe JR (1989) Evaluation of specific drought avoidance traits as selection criteria. In: Baker FWG (ed) Drought resistance in cereals-theory and practice. ICSU Press, Paris, pp 151-164

Bidinger FR, Yadav OP (2008) Biomass heterosis as the basis for grain and stover yield heterosis in arid zone pearl millet (Pennisetum glaucum (L.) R. Br.) hybrids. Crop Sci (accepted)

Bidinger FR, Mahalakshmi V, Rao GDP (1987) Assessment of drought resistance in pearl millet [Pennisetum americanum (L.) Leeke]. I. Factors affecting yields in stress. Aust J Agric Res 38:37-48. doi:10.1071/AR9870037

Bidinger FR, Weltzien RE, Mahalakshmi V, Singh SD, Rao KP (1994) Evaluation of landrace topcross hybrids of pearl millet for arid zone environments. Euphytica 76:215-226. doi:10.1007/BF00022166

Bidinger FR, Yadav OP, Sharma MM, van Oosterom EJ, Yadav YP (2003) Exploitation of heterosis for simultaneous improvement in both grain and stover yields of arid zone pearl millet. Field Crops Res 83:13-26. doi:10.1016/ S0378-4290(03)00006-6

Bidinger FR, Bhasker Raj AG, Hash CT (2006) Zonal adaptation in pearl millet cultivar types. Indian J Genet Plant Breed 66:207-211

Ceccarelli S (1994) Specific adaptation and breeding for marginal areas. Euphytica 77:205-219. doi:10.1007/ BF02262633 
Ceccarelli S, Grando S (1991) Environment of selection and type of germplasm in barley breeding for low-yielding conditions. Euphytica 57:207-219. doi:10.1007/BF00039667

Ceccarelli S, Acevedo E, Grando S (1991) Breeding for yield stability in unpredictable environments, single traits, interaction between traits and architecture of genotypes. Euphytica 56:169-185. doi:10.1007/BF00042061

Ceccarelli S, Grando S, Impiglia A (1998) Choice of selection strategy in breeding barley for stress environments. Euphytica 103:307-318. doi:10.1023/A:1018647001429

Christinck A (2002) This seed is like ourselves-a case study from Rajasthan, India on the social aspects of biodiversity and farmers' management of pearl millet seed. Margraf Verlaf, Weikersheim, Germany, 190

Gomez KA, Gomez AA (1984) Statistical procedures for agricultural research. Wiley, London

Hall A, Blummel M, Thorpe W, Bidinger FR, Hash CT (2004) Sorghum and pearl millet as food-feed crops in India. Anim Nutr Feed Techn 4:1-15

Kelley TG, Parthasarathy Rao P, Weltzien ER, Purohit ML (1996) Adoption of improved cultivars of pearl millet in an arid environment: straw yield and quality considerations in western Rajasthan. Exp Agric 32:61-172

Khairwal IS, Yadav OP (2005) Pearl millet (Pennisetum glaucum) improvement in India-retrospect and prospects. Indian J Agric Sci 75:183-191

Khairwal IS, Rai KN, Yadav OP, Bhatnagar SK (2004) Pearl millet cultivars. All India Coordinated Pearl Millet Improvement Project, Mandor, $22 \mathrm{pp}$

Mahalakshmi V, Bidinger FR, Rao GDP (1988) Timing and intensity of water deficits during flowering and grain filling in pearl millet. Agron J 80:130-135

Presterl T, Weltzien E (2003) Exploiting heterosis in pearl millet population breeding in arid environments. Crop Sci 43:767-776

Simmonds NW (1991) Selection for local adaptation in a plant breeding programme. Theor Appl Genet 82:363-367. doi:10.1007/BF02190624

van Oosterom EJ, Mahalakshmi V, Arya GK, Dave HR, Gothwal BD, Joshi AK et al (1995) Effect of yield potential, drought escape and drought tolerance on yield of pearl millet (Pennisetum glaucum) in different stress environments. Indian J Agric Sci 65:629-635

van Oosterom EJ, Whitaker ML, Weltzien-Rattunde E (1996) Integrating genotype by environment analysis, characterisation of drought patterns, and farmer preferences to identify adaptive plant traits for pearl millet. In: Cooper M, Hammer GL (eds) Plant adaptation and crop improvement. CAB International/IRRI/ICRISAT, Wallingford, pp 382402

vom Brocke K, Presterl T, Christinck A, Weltzien RE, Geiger HH (2002) Farmers' seed management practices open up new base populations for pearl millet breeding in a semiarid zone of India. Plant Breed 121:36-42. doi:10.1046/ j.1439-0523.2002.00657.x

vom Brocke K, Weltzien E, Christinck A, Presterl T, Geiger HH (2003) Effects of farmers' seed management on performance and adaptation of pearl millet in Rajasthan, India. Euphytica 130:267-280. doi:10.1023/A:1022830925717

Weltzien E, Fischbeck G (1990) Performance and variability of local barley landraces in near-eastern environments. Plant Breed 104:58-67. doi:10.1111/j.1439-0523.1990.tb00403.x

Yadav OP, Bidinger FR (2007) Utilization, diversification and improvement of landraces for enhancing pearl millet productivity in arid environments. Ann Arid Zone 46:49-57

Yadav OP, Weltzien RE (1998) New populations of pearl millet for Rajasthan, India. Integrated Systems Project Report No. 10. International Crops Research Institute for the Semi-Arid Tropics, Patancheru, India $88 \mathrm{pp}$

Yadav OP, Weltzien RE (2000) Differential response of pearl millet landrace-based populations and high yielding varieties in contrasting environments. Ann Arid Zone 39:39-45

Yadav OP, Weltzien RE, Mahalakshmi V, Bidinger FR (2000a) Combining ability of pearl millet landraces originating from arid areas of Rajasthan, India. Indian J Genet Plant Breed 60:45-53

Yadav OP, Weltzien-Rattunde E, Bidinger FR, Mahalakshmi V (2000b) Heterosis in landrace-based topcross hybrids of pearl millet across arid environments. Euphytica 112:285295. doi:10.1023/A:1003965025727 